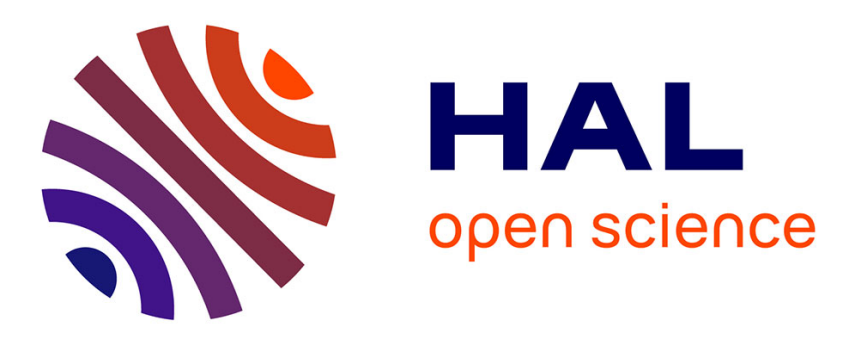

\title{
Vent sizing: Analysis of the blowdown of a hybrid non tempered system
}

Luc Véchot, Wilfried Saturnin Minko, Jean-Pierre Bigot, Marc Kazmierczak, Patricia Vicot

\section{- To cite this version:}

Luc Véchot, Wilfried Saturnin Minko, Jean-Pierre Bigot, Marc Kazmierczak, Patricia Vicot. Vent sizing: Analysis of the blowdown of a hybrid non tempered system. Journal of Hazardous Materials, 2011, 191 (1-3), pp.8-18. 10.1016/j.jhazmat.2011.03.100 . hal-00598542

\section{HAL Id: hal-00598542 \\ https://hal.science/hal-00598542}

Submitted on 11 Jun 2011

HAL is a multi-disciplinary open access archive for the deposit and dissemination of scientific research documents, whether they are published or not. The documents may come from teaching and research institutions in France or abroad, or from public or private research centers.
L'archive ouverte pluridisciplinaire HAL, est destinée au dépôt et à la diffusion de documents scientifiques de niveau recherche, publiés ou non, émanant des établissements d'enseignement et de recherche français ou étrangers, des laboratoires publics ou privés. 


\title{
Vent sizing: Analysis of the blowdown of a hybrid non tempered system
}

\author{
LUC VÉCHOT ${ }^{a(1)}$, WiLFRIED MiNKO ${ }^{b(1)}$, J EAN-PIERRE BIGOT(1), MARC KAZMIERCZAK(2), \\ PATRICIA ViCOT ${ }^{(2)}$
}

(1) Ecole Nationale Supérieure des Mines de Saint Etienne ; Centre SPIN ; Département GENERIC ; 158 Cours Fauriel ; 42023 Saint-Étienne Cedex 2, France

(2) INERIS, B.P. 2, 60550 Verneuil en Halatte, France

\begin{abstract}
The runaway and blowdown of a non tempered hybrid chemical system (30\% cumene hydroperoxide) exposed to an external heat input was investigated using a $0.1 \mathrm{l}$ scale tool.

The maximum temperature and the maximum temperature rise rate were showed to be sensitive to the vent size. An Antoine type correlation between the maximum temperatures and pressures was observed. These resulted from the presence of vapour, mainly generated by the reaction products. Increasing the initial filling ratio resulted in an earlier vent opening but did not have a significant influence on the blow-down. Three types of mass venting behaviour were observed, when changing the vent area to volume ratio $(A / V)$ :

* for large $A / V$, two-phase venting occurred from the vent opening until the end of the second pressure peak;

* for medium $A / V$, two-phase venting occurred before and after the turnaround. The data seem to indicate that gas only venting occurred at turn-around;

* for low $A / V$, two-phase venting was observed only after the second pressure peak.
\end{abstract}

Two-phase venting after the second pressure peak probably results from the boiling of the hot reaction products at low pressure.

Keywords:

Safety vent sizing; Run-away; Blowdown; Non tempered system; Cumene hydroperoxide

\section{Introduction}

DIERS $^{c}$ research work introduced a classification for runaway reactions according to which chemical systems are either tempered or non tempered (with vapour and gassy systems as limiting cases). According to Huff or Leung "the so-called tempering condition is achieved if the evaporative heat removal becomes equal to the reaction heat release" [1] and [2]. As a consequence, "the ERS ${ }^{\mathrm{d}}$ device is able to control $T(\mathrm{~d} T / \mathrm{d} t=0)$ and $P(\mathrm{~d} P / \mathrm{d} t=0)$ at the set pressure". On the other hand, "the ERS device is not able to control $T(\mathrm{~d} T / \mathrm{d} t>>0)$ and $P$ $(\mathrm{d} P / \mathrm{d} t>>0)$ at the set pressure" for hybrid non tempered reactions [3]. A "tempering effect"

\footnotetext{
a Present address: Texas A\&M University at Qatar, Education City, PO Box 23874, Doha, Qatar.luc.vechot@qatar.tamu.edu

b Present address: IRSN, B.P. 17, 92262 Fontenay-aux-Roses cedex, France., wilfried.minko@irsn.fr

c Design Institute for Emergency Relief Systems.

d Emergency Relief System.
} 
is however sometimes mentioned when vaporization phenomena reduce the reacting mixture temperature and the severity of runaway reaction, without controlling the temperature [4].

DIERS vent sizing methodology was largely developed and used for tempered systems [3]. A method was also proposed for purely gassy systems [5], but very few investigations were published for hybrid non tempered systems. No vent sizing criterion that would take vapour influence into account is available although it was demonstrated that it greatly modifies the necessary vent size [6], [7], [8], [9] and [10].

Few experiments involving the runaway and blowdown of non tempered systems were published [11], [12], [13], [14] and [15]. These tests were performed with the objective of developing the UN 101 method based on the similarity principle.

The present work was aimed to gain a better understanding of the blowdown of non tempered hybrid systems, and more precisely to observe the sensitivity of the temperature, pressure and vented mass to the vent area to vessel volume ratio $(A / V)$. The experimental study uses a recently developed $0.1 \mathrm{l}$ scale tool [6] and [16]. Adiabatic calorimetry tests with closed and open cells according to the DIERS methodology were also carried out prior to the blowdown tests. They allowed the characterization of the thermodynamic and the kinetics of the runaway reaction of concern.

\begin{tabular}{|c|c|c|c|}
\hline \multicolumn{2}{|r|}{ Nomenclature } & \multicolumn{2}{|r|}{ Index } \\
\hline $\mathrm{A} / \mathrm{V}$ & $\begin{array}{l}\text { Vent area to reactor (or test cell) volume } \\
\text { ratio }\left(\mathrm{m}^{-1}\right)\end{array}$ & ini or $\mathrm{o}$ & at the beginning of test, before reaction begins \\
\hline $\mathrm{CHP}$ & Cumene Hydro peroxide & $\max$ & when pressure is maximum (i.e. at turnaround) \\
\hline $\mathrm{m}$ & Mass of reactor (or test cell) contents $(\mathrm{kg})$ & end & at the end of blowdown, after cooling down \\
\hline $\mathrm{P}$ & $\begin{array}{l}\text { Absolute pressure in reactor (or test cell) } \\
\text { (bar) }\end{array}$ & $\mathrm{s}$ & at vent opening (i.e. at set pressure) \\
\hline $\mathrm{T}$ & Temperature in reactor (or test cell) $\left({ }^{\circ} \mathrm{C}\right)$ & & \\
\hline $\mathrm{T}_{\mathrm{bp}}$ & $\begin{array}{l}\text { Boiling temperature at ambient pressure } \\
\qquad\left({ }^{\circ} \mathrm{C}\right)\end{array}$ & & \\
\hline$\tau$ & Filling ratio (\%) & & \\
\hline$\Delta \mathrm{t}$ & $\begin{array}{l}\text { Time between safety vent opening and } \\
\text { turnaround (s) }\end{array}$ & & \\
\hline
\end{tabular}

\section{Experimental set up}

\section{II.1. DIERS adiabatic calorimetry}

Closed and open cell tests according to the DIERS approach were carried out using a Vent Sizing Package 2 (VSP2) adiabatic calorimeter (Fauske \& Associates, LLC). Closed cell experiments consist in performing the runaway reaction under adiabatic conditions in a $110 \mathrm{ml}$ closed cell. The gases/vapour generated by the runaway reaction pressurise the test cell. Open cell experiments consist in performing the runaway reaction in a $110 \mathrm{ml}$ test cell open to a $4 \mathrm{l}$ containment vessel. In this case, the generated gases/vapour pressurise a larger volume, thus avoiding the bursting of the test cell. For both configurations the liquid temperature and the generated pressure (either in the test cell or in the containment vessel) are recorded. All the open and closed tests were performed with stainless steel test cells.

\section{II.2. Setup for blowdown experiments at laboratory scale}

A recently developed 0.11 scale tool ([6] and [16], Figure 1) was used to run blowdown experiments at laboratory scale. This tool is an extension of the VPS2 adiabatic calorimeter in its blowdown configuration which consists in the addition of a main safety relief line, a feed bleed line and a real time vented mass measurement system. The main safety relief line (1/8" 
diameter, $0.6 \mathrm{~m}$ long) includes an actuated ball valve, which simulates the opening of the safety relief system, followed by a metering valve where most of the pressure drop occurs. An equivalent $\mathrm{A} / \mathrm{V}$ ratio can be defined for different settings of the metering valve. Stainless steel test cells were used for all the tests. This experimental setup allows the measurement of the liquid temperature, the cell pressure and the vented mass during the blowdown. The small scale of the experimental setup allows the study of the sensitivity of the blowdown to the A/V ratio. The measurement of the vented mass is subsequently used to assess the vented mass at turnaround (second pressure peak).

\section{Chemical system and experimental conditions}

Cumene hydroperoxide (CHP; $\mathrm{Tbp}=116^{\circ} \mathrm{C}$ at 20 mbar abs pressure) and 2,2,4-trimethyl-1,3pentanediol diisobutyrate $\left(\mathrm{Tbp}=280^{\circ} \mathrm{C}\right.$ at atmospheric pressure) were chosen respectively as the substance subject to thermal decomposition and the solvent. CHP is widely used as an initiator for polymerization reactions. It decomposes to mainly produce methane (0.3$0.5 \mathrm{~mol} / \mathrm{mol})$, dimethylbenzyl alcohol (0.6-0.9 mol $/ \mathrm{mol})$, acetophenone $(0.2-0.4 \mathrm{~mol} / \mathrm{mol})$, and phenol and acetone when cumene is present $(\approx 0.06 \mathrm{~mol} / \mathrm{mol} \mathrm{each})$ [17].

The decomposition of $30 \%(\mathrm{w} / \mathrm{w})$ CHP under external heat input conditions of $\mathrm{d} T / \mathrm{d} t=0.5{ }^{\circ} \mathrm{C} \mathrm{min}^{-1}\left(0.0083{ }^{\circ} \mathrm{C} \mathrm{s}^{-1}\right.$, fire simulation) was studied. CHP was obtained as a 80\% $(\mathrm{w} / \mathrm{w})$ solution in cumene. The composition of the investigated chemical mixture is therefore $30 \%(\mathrm{w} / \mathrm{w})$ CHP, $7.5 \%$ cumene and $62.5 \%$ solvent. It has to be noted that cumene $\left(T_{\mathrm{bp}}=153{ }^{\circ} \mathrm{C}\right)$ is the most volatile chemical in this mixture. Assuming no decomposition, this mixture would lead to a vapour pressure of around 0.8 bar at $250^{\circ} \mathrm{C}$.

\section{Results of the experimental investigation}

\section{IV.1. Characterisation of the chemical system using the DIERS approach}

\section{IV.1.1. Procedure}

For both open and closed cell experiments, the chemical mixture is first quickly heated up $\left(\sim 3{ }^{\circ} \mathrm{C} \mathrm{min}{ }^{-1}\right)$ to $85{ }^{\circ} \mathrm{C}$ (at this temperature the decomposition reaction is very slow and can not be detected by the VSP2 in adiabatic mode). External fire exposure is then simulated through constant power input $\left(0.5{ }^{\circ} \mathrm{C} \mathrm{min}^{-1}\right)$ until the end of the decomposition.

\section{IV.1.2. Results of the closed cell experiments [6] and [16]}

We had to lower CHP concentration to $15 \%(\mathrm{w} / \mathrm{w})$ for the closed cell DIERS calorimetric tests in order to avoid the bursting of the cell. The closed cell experiment however provided some qualitative information about vapour and non-condensable gas production during the runaway reaction. Table 1 and Figure 2a give the test conditions and main results. As expected, the pressure at the end of the closed cell experiment, after cooling $P_{\text {end }}=9.4 \mathrm{bar}$ after correction for the pad gas clearly indicated that the decomposition of CHP leads to the formation of non-condensable gases.

Two rough assumptions were made in order to estimate possible presence of vapour during the post decomposition period (cooling down to ambient temperature):

\section{The vapour contents are completely condensed at $T_{\text {end }}$.}

* The non-condensable gases are not soluble in the liquid phase, independently of the temperature.

After correcting for the pad gas, it is possible to assess the respective contributions of the non condensable gases and the vapour to the total pressure during the cooling period. Figure $2 b$ shows that a linear Antoine type plot can be obtained for the assessed vapour pressure between $83{ }^{\circ} \mathrm{C}$ and $T_{\max }\left(242^{\circ} \mathrm{C}\right)$. Vapour would thus contribute to $P_{\max }$ as high as 10.4 bar, which would be significant compared to 16 bar for non condensable gases.

The vapour pressure would be around 4 bar at $150^{\circ} \mathrm{C}$ after decomposition whereas the pressure (non condensable + vapour) is almost zero at the same temperature before decomposition starts (Figure 2a). This means that the vapour pressure is mainly due to the 
decomposition products. When dealing with an unknown reaction, it is therefore necessary to investigate the presence of vapour not only before decomposition occurs, but also after its completion.

The presence of vapour is consistent with mechanisms proposed by both Levin et al. [18] and Kharasch et al. [17]. However the generation of non condensable gases clearly occurs during our experiments (9.4 bar observed after cooling, Figure 2a) [19]. The decomposition we observed seems thus more consistent with the mechanism proposed by Kharasch et al.

\section{IV.1.3. Results of the open cell experiments}

Open cell tests were performed to observe the influence of a pad pressure $\left(P_{0}\right)$ on reaction temperature and thus on the reaction kinetics. four tests were run using four different initial pad pressures and two initial filling ratios (Table 2; [Figure 3] and [Figure 4]) with a solution of $30 \%$ CHP.

Table 2 shows that $T_{\max }$ decreases when decreasing $P_{0}$, which is a result of some energy being consumed by more vaporization. Low pad pressures are indeed more favourable for the existence of vaporisation phenomena ${ }^{\mathrm{e}}$. The vaporization would consume an amount of energy such that the liquid temperature cannot exceed $250{ }^{\circ} \mathrm{C}$ during a blowdown experiment if the pressure is always below 2 bar ([Figure 3] and [ Figure 4]). The DIERS approach assumes thus that vents can then be sized using the maximum reaction rate under maximum allowed pad pressure at that temperature [20].

Two facts have to be noted about these experiments:

- The volume of the mixture remaining in the cell at the end of tests at $P_{0}=1$ bar and $P_{0}=4.5$ bar is so low that the cell thermocouple is no longer inside the liquid, which could lead to an erroneous temperature measurement and a larger $\varphi$ adiabaticity factor.

* Two-phase choking flow occurs within test cell pipe during test with $P_{\mathrm{o}}=4.5$ bar when reaction kinetics reach their maximum (Figure $3 \mathrm{~b}$ ).

Open tests under a large initial pad pressure $\left(P_{\mathrm{o}}=16\right.$ bar and $P_{\mathrm{o}}=26$ bar; Figure a and b) do not show any measurable temperature or time lag between $(\mathrm{d} P / \mathrm{d} t)_{\max }$ and $(\mathrm{d} T / \mathrm{d} t)_{\max }$. This could be due to vaporization being weak at those pressures. The test at $P_{0}=4.5$ bar exhibits a $10{ }^{\circ} \mathrm{C}$ temperature lag and a $0.26 \mathrm{~s}$ time lag between $(\mathrm{d} T / \mathrm{d} t)_{\max }$ and $(\mathrm{d} P / \mathrm{d} t)_{\max }$ but it could be due to choked two-phase flow occurring inside the cell tube or thermocouple time constant. Temperature lag for the test at $P_{\mathrm{o}}=1 \mathrm{bar}$ is not easy to read (may be $5{ }^{\circ} \mathrm{C}$ ). Therefore, it seems that using the temperature or the time lag between $(\mathrm{d} P / \mathrm{d} t)_{\max }$ and $(\mathrm{d} T / \mathrm{d} t)_{\max }$ as a criterion to detect the presence of vapour [19] is much less obvious than comparing $T_{\max }$ for different $P_{\mathrm{o}}$.

IV.2. Blowdown experiments ( 0.11 scale) with $P, T$ and $m(t)$ measurements

IV.2.1. Description of a blowdown test

Similarly to the DIERS calorimetry tests described above, the blowdown experiments involved the rapid heating of the chemical mixture $\left(\sim 3{ }^{\circ} \mathrm{C} \mathrm{min}^{-1}\right)$ to $85{ }^{\circ} \mathrm{C}$. External fire exposure is then simulated through constant power input $\left(0.5^{\circ} \mathrm{C} \mathrm{min}{ }^{-1}\right)$ until the end of the experiment. The chosen set pressure (vent opening pressure) for the blowdown experiments is 4.5 bar. The feed-bleed line is permanently open during experiment, except at the very beginning where it could lead to water from the mass measurement system flowing back into the cell.

e The decrease of $T_{\max }$ at lower pad pressure $\left(\mathrm{P}_{\mathrm{o}}\right)$ could alternatively be attributed to an increase of the $\varphi$ factor following the decrease of reactant mass in the test cell (up to 40.3/52.6 for $\mathrm{P}_{\mathrm{o}}=\mathrm{P}_{\mathrm{atm}}$, Table 2). The following discussion of blowdown experiments will show that this is probably not the main effect. 
The size of the feed-bleed line $\left(A / V<10^{-4} \mathrm{~m}^{-1}\right)$ which corresponds to a $1 \mathrm{~mm}$ nozzle for a $10 \mathrm{l}$ reactor [13] and the safety vent line $\left(10^{-3} \mathrm{~m}^{-1}<A / V<2.4 \times 10^{-3} \mathrm{~m}^{-1}\right)$ are first established.

Figure $5 \mathrm{a}$ shows the typical temperature and pressure curves obtained. A test lasts approximately $3 \mathrm{~h}$ but the blowdown itself lasts approximately 1 min only (Figure 5b). Liquid is still vented for one more minute.

\section{$I V .2 .2$. Results of the blowdown experiments}

Experiments were run for different values of the safety vent $A / V$ ratio and the initial filling ratio (Table 3). Note that test cell swelled during tests $\mathrm{A}$ and $\mathrm{K}$ inducing uncertainty about $A / V$ ratio. For a given initial filling ratio, all the experiments were intended to be as similar as possible until vent opening.

Figure 6 shows that the temperature of the liquid at vent opening $\left(T_{\mathrm{s}}\right)$ varies between $209{ }^{\circ} \mathrm{C}$ and $224{ }^{\circ} \mathrm{C}$ depending on the unavoidable slight changes in feed-bleed line $A / V$ ratio. Accordingly, the higher the temperature at vent opening $\left(T_{\mathrm{s}}\right)$, the shorter the time between vent opening and turnaround ( $\Delta t$, Figure 7 ).

All tests showed a quick pressure drop at vent opening without any temperature decrease until a second pressure peak occurred (when reaction rate is at its maximum, Figure $5 \mathrm{~b}$ ). This means that temperature is not (directly) controlled by pressure, which is typical of a non tempered system [3].

However, Figure 8 shows that temperature rise rate $(\mathrm{d} T / \mathrm{d} t)$ presents a discontinuity at safety vent opening (around $210{ }^{\circ} \mathrm{C}$ ). The larger the $A / V$ ratio (and thus the larger the pressure drop), the larger the discontinuity. This demonstrates that some vapour is already present at this stage. Increasing $A / V$ ratio (thus lowering average pressure during blowdown) results in decreasing $(\mathrm{d} T / \mathrm{d} t)_{\max }$ and $T_{\max }$. This is very similar to the effect of decreasing nitrogen pad pressure $\left(P_{0}\right)$ during a DIERS open cell test (Figure 4$)$.

Figure 9 shows the comparison between two tests performed with the same initial filling ratio but with different values of $A / V$ (tests $\mathrm{B}$ and $\mathrm{C}$ ). It can be seen that the vented mass for these two tests is low and almost the same up to $30 \mathrm{~s}$ after vent opening (close to turnaround for test B). The observed differences in temperature rise rate $(\mathrm{d} T / \mathrm{d} t)$ after vent opening cannot be explained by a difference of $\varphi$ factor resulting from the decrease of reactant mass in the test cell. This effect has thus to be associated with some tempering due to volatile decomposition products.

Figure 10 shows that both $P_{\max }$ and $(\mathrm{d} P / \mathrm{d} t)_{\max }$ decrease when $A / V$ increases with no detectable influence of initial filling ratio.

Figure 11 shows that an Antoine type correlation exists between pressure and temperature at turnaround ( $P_{\max }$ and $T_{\max }$ ), independently of the filling ratio (between $46 \%$ and $80 \%$ ). This pressure is much lower than the vapour pressure observed after the closed cell tests with $15 \%$ (w/w) CHP concentration (Figure 2). This could mean that this pressure does not result from a thermodynamic equilibrium. The independence of that pressure to initial filling ratio could mean that this correlation is (at least partially) due to the vaporization kinetics. It is a further evidence of the influence of vaporization on the blowdown.

Figure 12a and $\mathrm{b}$ show the results obtained from blowdown experiments performed with the same $A / V$ for both the feed-bleed line and the safety vent line, while only varying the initial filling ratio $\tau_{0}$. It can be observed that an increase of the initial filling ratio leads to:

* A small $\left(<12{ }^{\circ} \mathrm{C}\right)$ decrease of the temperature at vent opening $\left(T_{\mathrm{s}}\right)$. Less volume being available for the gas with a higher initial filling ratio, the pressure build-up is quicker and therefore the vent opening pressure is reached at an earlier stage of the reaction;

* An increase of the time between the two pressure peaks as a consequence of the decrease of the temperature at vent opening.

These effects are more obvious for experiments $\mathrm{C}$ and $\mathrm{G}$ (Figure 12a) than for experiments $\mathrm{H}$ and $J$ (Figure 12b). In both cases, an increase of $P_{\max }, T_{\max }$ and mass vented at turnaround $\left(\Delta \mathrm{m} / \mathrm{m}_{\mathrm{o}}\right.$ at turnaround) of less than $20 \%$ was observed. These tests showed that the sensitivity 
of other parameters (including $(\mathrm{d} T / \mathrm{d} t)_{\max }$ and $\left.(\mathrm{d} P / \mathrm{d} t)_{\max }\right)$ to the initial filling ratio is low (within the measurement error, see Table 3).

\section{Discussion}

\section{V.1. Tempering of a non tempered systems}

There is enough vaporization during both open cell and blowdown experiments to change Tmax (Figure 4 and [Figure 8). The vaporization phenomena are even enough for Pmax to be correlated with Tmax during blowdown experiments. This means that the $30 \%$ CHP system is subject to some tempering [4]. On the other hand vaporization during blowdown experiments does not prevent the reactive mixture temperature increase when the pressure drops at vent opening, resulting in a typical two pressure peak behaviour (Figure 5a and b). CHP is therefore a hybrid non tempered $\operatorname{system}^{\mathrm{f}}$ [1], [2] and [3].

\section{V.2. Mass loss histories}

The real time measurement of the vented mass downstream the safety vent allows the investigation of the phenomena occurring during the blowdown. Three types of behaviour have been observed (Figure 13a-c).

The attention is first focused on the case of a blowdown experiment with a small $A / V$ ratio (type I, $A / V<0.96 \times 10^{-3} \mathrm{~m}^{-1}$; Figure 13a). No vented mass is recorded during the blowdown until the pressure decrease of the second pressure peak (i.e. after turnaround). This means that flow is only gas during this period. This results from the pressure between the two peaks being never less than 2.1 bar and pressure at turnaround being large ( $\left.P_{\max }=25.8 \mathrm{bar}\right)$. This pressure is believed to be sufficient to limit level swell or boiling effects, even when the temperature and reaction kinetics (and thus volatile species production) reach their maximum. Mass loss (around $20 \times 10^{3} \mathrm{~kg} \mathrm{~m}^{-2} \mathrm{~s}^{-1}$ ) starting $20 \mathrm{~s}$ after the safety vent opening (see small pressure accident) is consistent with two-phase flow. The decomposition reaction is finished at that time and no more non condensable gas is produced. Two-phase flow can thus only result from boiling and release of dissolved gases induced by pressure decrease at large temperature. This process results in the venting of up to $75 \%$ of initial mass.

For medium sized safety vents (type II, $0.96 \times 10^{-3}<A / V<1.56 \times 10^{-3}$, Figure $13 \mathrm{~b}$ ) the pressure drops from 4.5 bar down to less than 2 bar in a few seconds after safety vent opening. This lower pressure induces level swell and two-phase flow, even at that early stage of the blowdown where both temperature and reaction kinetics are quite far from their maximum (just before turnaround). 10\% of the initial cell contents are already vented between the two pressure peaks. Mass flow through the vent is therefore probably due to level swell induced by gas production. The exponential temperature increase just prior the turnaround leads to a significant increase of the gas generation rate and thus to a pressure increase. This latter prevents boiling. It compresses both gas and vapour, which tends to promote gas disengagement despite an increase in gas and vapour production rate. The above is an attempt to explain the observed mass flow rate decrease at the beginning of the second pressure peak. Two-phase flow due to boiling after the turnaround (around 40\% of initial mass) can again be observed.

For larger safety vents (type III, $A / V>1.56 \times 10^{-3} \mathrm{~m}^{-1}$; Figure $13 \mathrm{c}$ ), two-phase venting occurs during the whole blowdown because of the pressure being lower, which promotes level swell.

${ }^{\mathrm{f}}$ We moreover observed no change in temperature rise rate during open cell tests at low pressure. This could be consistent with vapor species being products of the reaction directly produced as vapor phase when initial pressure is low. The same species being produced as liquid when pressure is higher. 
These three types of behaviour show that the vapour contents have more effect on vent flow during and after the second pressure peak than during runaway reaction itself. Indeed, this is when the temperature is the highest and decomposition reaction has already generated volatile species.

Figure 14 shows that mass vented at turnaround increases when $A / V$ ratio increases. This is probably due to the fact that lower pressure induces more level swell. However, Figure 15 shows that the total vented mass (including mass vented after the second pressure peak) remains almost unchanged (between $45 \%$ and $65 \%$ ) for all $A / V$ ratios. This could be related to the total vapour production ratio remaining unchanged.

\section{Conclusions}

Our investigation is focused on the behaviour of a hybrid non tempered runaway reaction under blowdown conditions. The DIERS approach (closed and open cell tests) shows that CHP decomposition produces both vapour and non condensable gases. The analysis of the post-decomposition data shows that vapour species are mainly products of the reaction. They are thus most easily detected after decomposition ends. The decomposition seems consistent with the mechanism proposed by Kharasch et al. [17]. Vaporisation has a significant effect on $T_{\max }$ and $(\mathrm{d} P / \mathrm{d} t)_{\max }$, especially at low initial pad gas pressure. $30 \%$ CHP in butyrate solvent is thus a hybrid system. The detection of the hybrid characteristic of the system using temperature or time lag between $(\mathrm{d} P / \mathrm{d} t)_{\max }$ and $(\mathrm{d} T / \mathrm{d} t)_{\max }$ is much less obvious.

All the blowdown experiments present a profile with two pressure peaks typical of non tempered gas producing systems, independently of the $A / V$ ratio. The time between the two pressure peaks $(\Delta t)$ mainly depends on the temperature at vent opening. These experiments are quite reproducible $\left(209^{\circ} \mathrm{C}<T_{\mathrm{s}}<224^{\circ} \mathrm{C}\right)$.

The pressure drop at vent opening leads to a decrease of temperature rise rate. This effect can be related to the vaporisation of decomposition products favoured by the low level of pressure following the vent opening. The maximum temperature and maximum temperature rise rate are also sensitive to the vent size. The kinetics of the studied decomposition is thus sensitive to the vaporisation of decomposition products. This vaporisation is sufficient to result in an Antoine type correlation between $P_{\max }$ and $T_{\max }$. This correlation does however not correspond to equilibrium.

Increasing the initial filling ratio mainly results in an earlier vent opening (quicker pressure build-up to the vent opening pressure because of a smaller gas space). The temperature at vent opening $\left(T_{\mathrm{s}}\right)$ is consequently slightly lower, which results in a longer delay between the two peaks. The sensitivity to initial filling ratio is however visible neither on maximum pressure nor on maximum pressure rise rate, nor on vented mass ratio (at turnaround or total).

The relative vented mass $\left(\Delta m / m_{0}\right)$ at turnaround increases with the $A / V$ ratio (from $o$ to $45 \%)$, probably because pressure being lower. Two-phase flow through the vent is always observed after the second pressure peak despite the reaction is complete. The relative amount of final vented mass is relatively independent (between 45 and 62\%) of both the initial filling ratio and the $A / V$ ratio. It could be due to the boiling of the hot reaction products at low pressure.

Three types of blowdown behaviours have been observed. For these three behaviours, the pressure profiles show a typical two pressure peak shape and significant mass venting is observed after turnaround, when the reaction is complete. The observed post-turnaround mass flow is probably due to the boiling (at high temperature) of the vessel contents when the pressure decreases. It could alternatively be due to foaming character or to gas desorption. The vented flow at turnaround could be either gas (low $A / V$ ratio, type I) or two-phase (large $A / V$ ratio, type III). It seems gas venting could occur at turnaround even when it is two-phase just before and just after that moment (medium $A / V$ ratio, type II). There is thus a trend towards gas disengagement and gas one-phase flow (revealed by less or no vent mass flow rate) when pressure increases towards the 2nd pressure peak. 
Many complements to this study could be of an interest in order to approach a better understanding of the blowdown of non tempered systems:

* addition of a real time measurement of vented volume (non condensable gases);

* study of other chemical systems in order to identify the specificities of CHP in the present study. Experiments with a chemical system with less vapour production would be of particular interest;

* experiments with the same systems at a larger scale for scale-up validation;

* discussion of vent sizing calculation from these experiments.

Some of these studies will be presented in a next article.

\section{References}

[1] J.E. Huff, Emergency venting requirements, Plant/Oper. Prog., 1(1982) 211-229.

[2] J.C. Leung, Venting of Runaway Reactions with Gas Generation, AIChE J., 38 (1992) 723-732

[3] H.G. Fisher, A.R. Muller, H.S. Forrest, J.A. Noronha, S.S. Grossel, D.A. Shaw, B.J. Tilley, Emergency Relief System Design Using DIERS Technology - The DIERS Project Manual. AICHE, 1992, pp. 365-448

[4] J.C. Leung, Simplified Vent Sizing Methods Incorporating Two-phase Flow, Int. Symp. on Runaway Reactions and Pressure Relief Design, Boston, MA. August 1995

[5] J.C. Leung, H.K. Fauske, Runaway System Characterisation and Vent Sizing Based on DIERS Methodology, Plant/Oper. Prog., 6 (1987) 77-83

[6] L. Véchot., Sécurité des procédés ; emballement de réaction ; dimensionnement des évents de sécurité pour systèmes " gassy » ou hybrides non tempérés; PhD thesis, Ecole Nationale Supérieure des Mines de Saint-Étienne, December 2006. http://tel.archivesouvertes.fr/tel-00136503/fr/

[7] L. Véchot, J.P. Bigot., M. Kazmierczak., P. Vicot, Non-tempered systems; Discussion on vented mass measurements, EDUG Meeting, London, June 2006.

[8] W. Minko, J.P. Bigot, Looking for a purely gassy system; European DIERS Users Group (EDUG) conference, Frankfort, 6-7 September 2007

[9] W. Minko, L. Véchot, J.P. Bigot, Vent sizing for un-tempered systems: Scale-up issues, DIERS vs similarity methods comparison, Possible way of study, IGUS - EOS meeting, Stockholm, 14-15 May 2008

[10] W.Minko, Emballements thermiques de réactions : Etude des méthodes de dimensionnement des évents applicables aux systèmes hybrides non tempérés, $\mathrm{PhD}$ thesis, Ecole Nationale Supérieure des Mines de Saint-Étienne, December 2008. http://tel.archives-ouvertes.fr/tel-00372536/fr/

[11] J.A. Hare., W.D. Adams., Evaluation of the UN vent sizing method for organic peroxide portable tanks, Proceedings of IChemE Hazards XVI Symposium, IChemE ISBN o85295-441-7, Nov 2001, pp. 133-146.

[12] J.C. Etchells., T.J. Snee, A.J. Wilday, Relief System Sizing for Exothermic Runaway: The UK HSE Strategy, Proceedings of IChemE Hazards XV Symposium Series, Manchester 4-6 April 2000, 299-311, ISBN 0-85295-429-8.

[13] United Nations Economic Commission for Europe, Committee of Experts on the Transport of Dangerous Goods and on the Globally Harmonized System of Classification and Labelling of Chemicals (2003). Example of a test method for Vent sizing. Appendix 5 in "Recommendations on the Transport of Dangerous Goods, Manual of Tests and Criteria" pp. 421-425.

[14] C.S. Poteet III, M.L. Banks. An Example of a Test Method for Vent Sizing - OPPSD/SPI Methodology, Process Saf. Prog. 21 (2002) 85-96

[15] J.J. de Groot, D.M. Groothuizen, J. Verhoeff, Safety Aspects of Organic Peroxides in Bulk Tanks, Ind. Eng. Chem. Process. Des. Dev. 20 (1981) 131-138. 
[16] L. Véchot., J.P. Bigot, D. Testa, M. Kazmierczak, P. Vicot, Runaway reaction of nontempered chemical systems: Development of a similarity vent-sizing tool at laboratory scale, J. Loss Prev. Process Ind. 21 (2008) 359-366.

[17] M.S. Kharasch, A. Fono, W. Nudenberg, The chemistry of hydroperoxides. VI. The thermal decomposirion of a-cumyl hydroperoxide, J. Org. Chem. 16 (1951) 113-127.

[18] M.E. Levin., N.O. Gonzales, L.W. Zimmerman., J. Yang, Kinetics of acid-catalyzed cleavage of cumene hydroperoxide., J. Hazard. Mater. 130 (2006) 88-106

[19] J.C. Leung, Chemical Process Relief Design Seminar, Ecole des Mines de Saint-Étienne (France), 2003.

[20] M.J. Creed, H.K. Fauske, An Easy, Inexpensive Approach to the DIERS Procedure, Chem. Eng. Prog. 6 (1990) 45-49

\section{Figures}

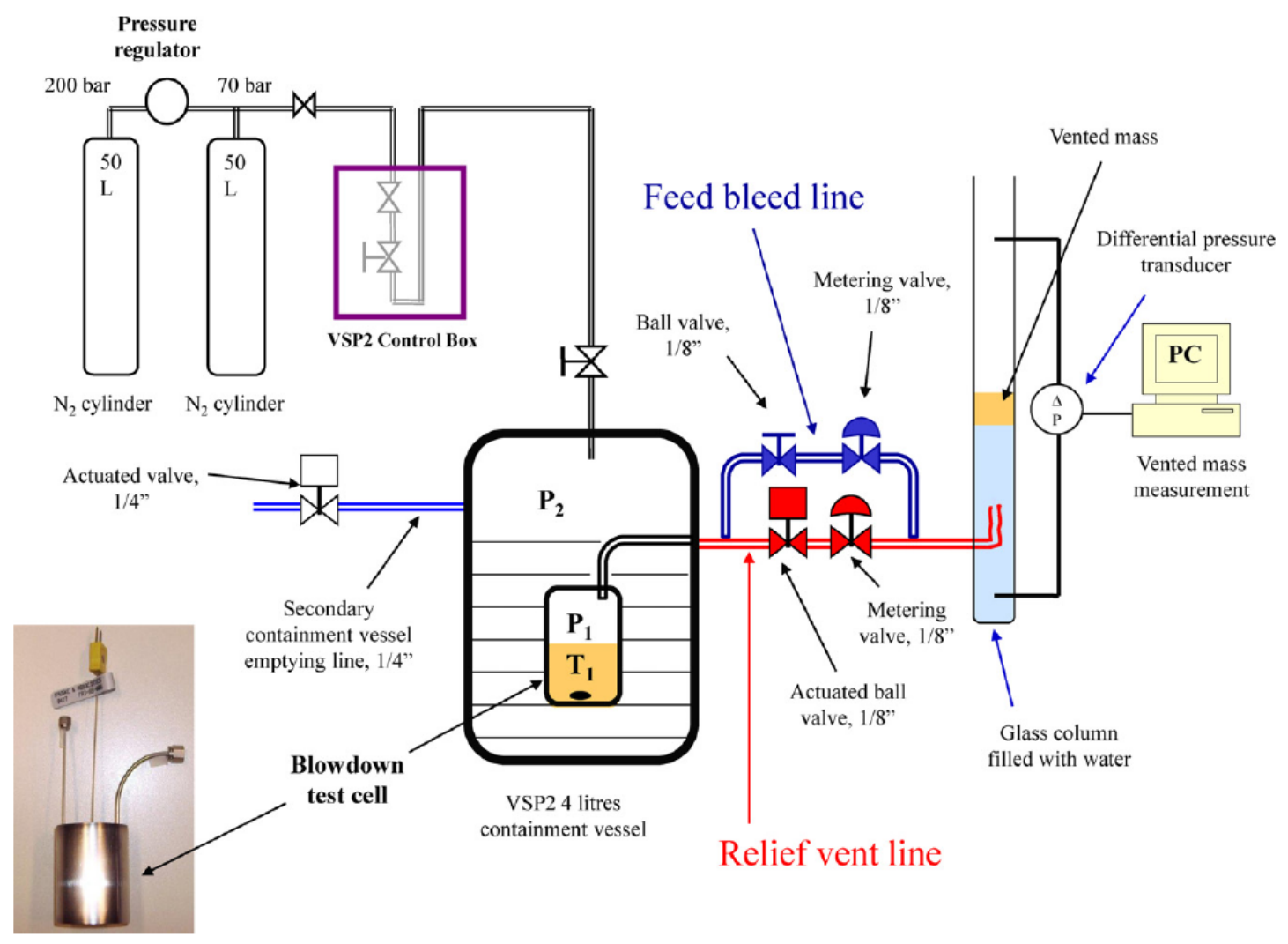

Figure 1: Scheme of the experimental set-up. 
Journal of Hazardous Materials, 2011, 191(1-3), 8-18, doi:10.1016/j.jhazmat.2011.03.100
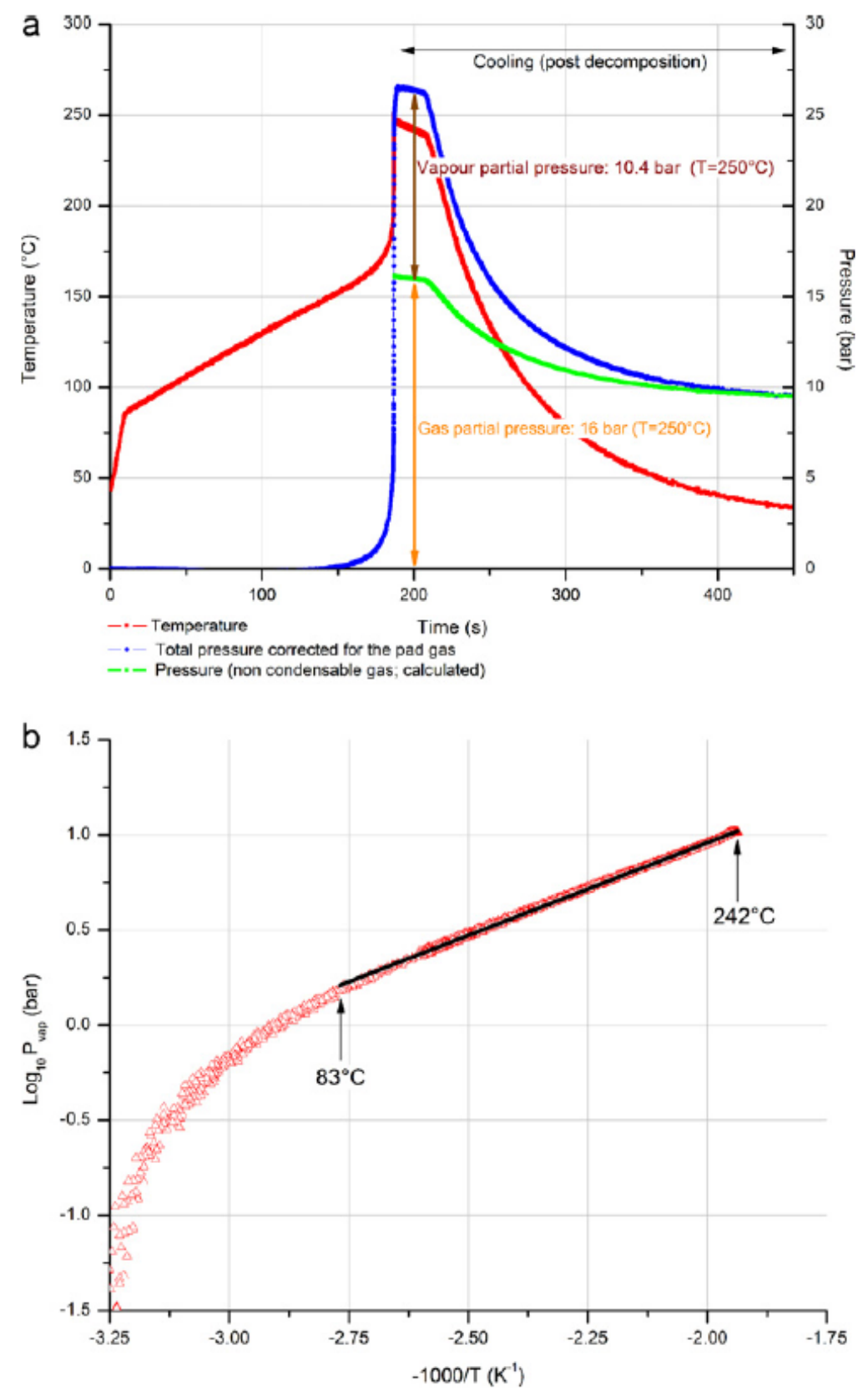

Figure 2: (a) Closed cell test - 15\% HPOC in 2,2,4-trimethyl-1,3-pentanediol diisobutyrate. (b) Closed cell test15\% HPOC in 2,2,4-trimethyl-1,3-pentanediol diisobutyrate - Antoine type plot obtained for the assessed vapour pressure between $83^{\circ} \mathrm{C}$ and $\operatorname{Tmax}\left(242^{\circ} \mathrm{C}\right)$. 

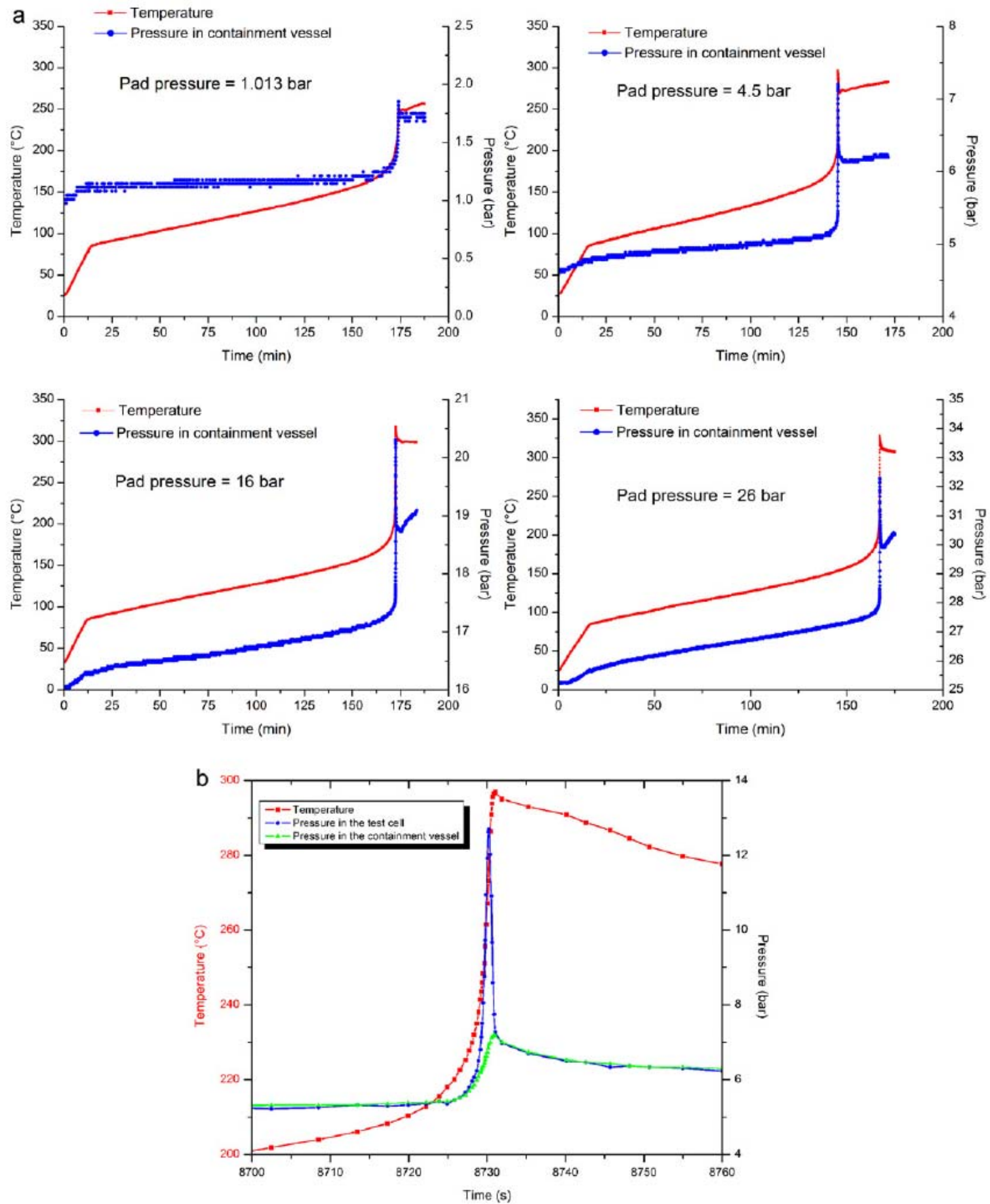

Figure 3: (a) 30\% CHP in 2,2,4-trimethyl-1,3-pentanediol diisobutyrate-open cell tests under Po of 1.o13, 4.5, 16 and 26 bar. (b) 30\% CHP in 2,2,4-trimethyl-1,3-pentanediol diisobutyrate-open cell tests under $P_{o}$ of 4.5 bar. 

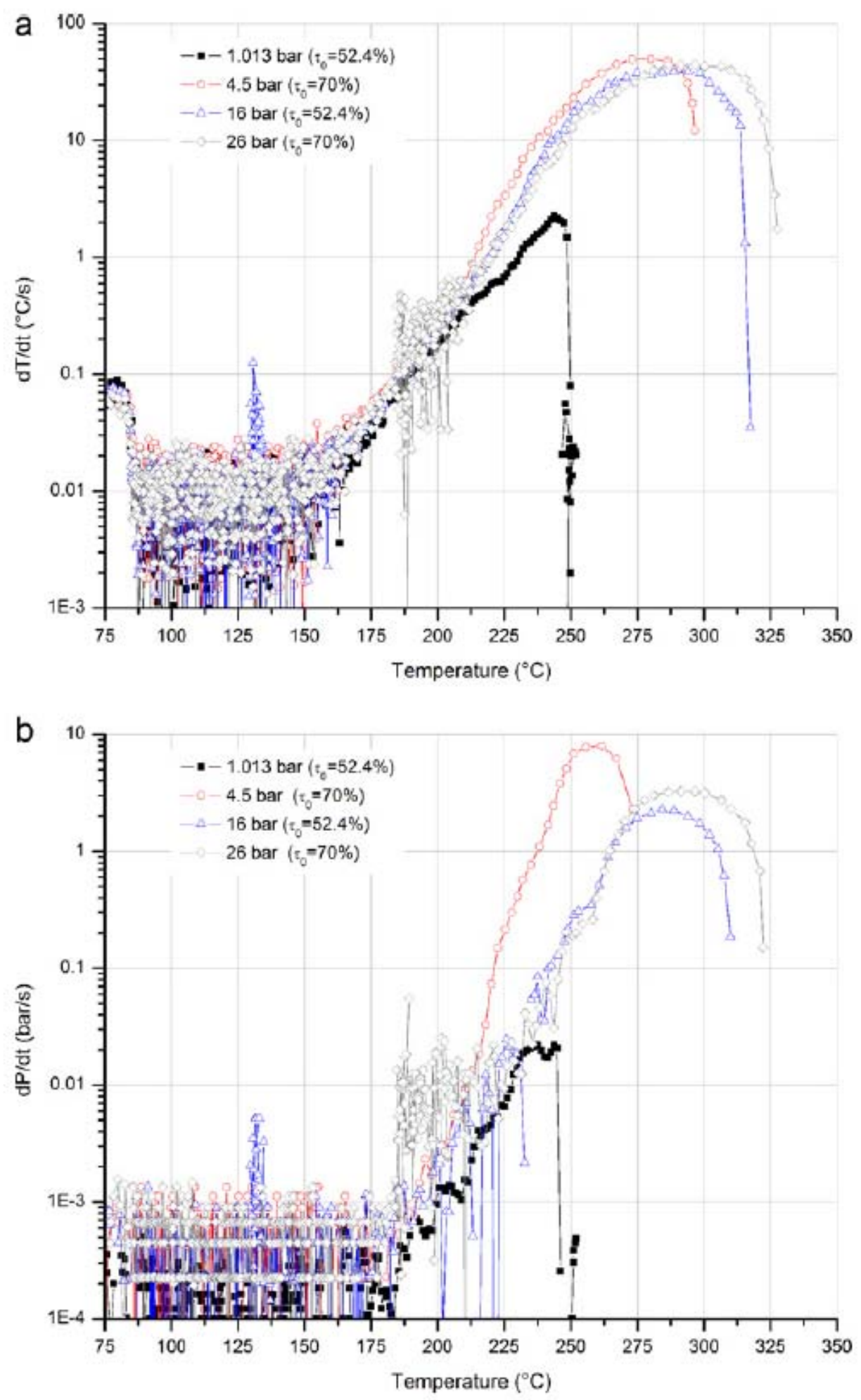

Figure 4: (a) 30\% CHP in butyrate $-d T / d t=f(T)$ for open cell tests with $P_{o}=1,4.5,16$ and 26 bar. (b) $30 \%$ CHP in butyrate $-d P / d t=f(T)$ for open cell tests with $P_{o}=1,4.5,16$ and 26 bar. 
Journal of Hazardous Materials, 2011, 191(1-3), 8-18, doi:10.1016/j.jhazmat.2011.03.100

a

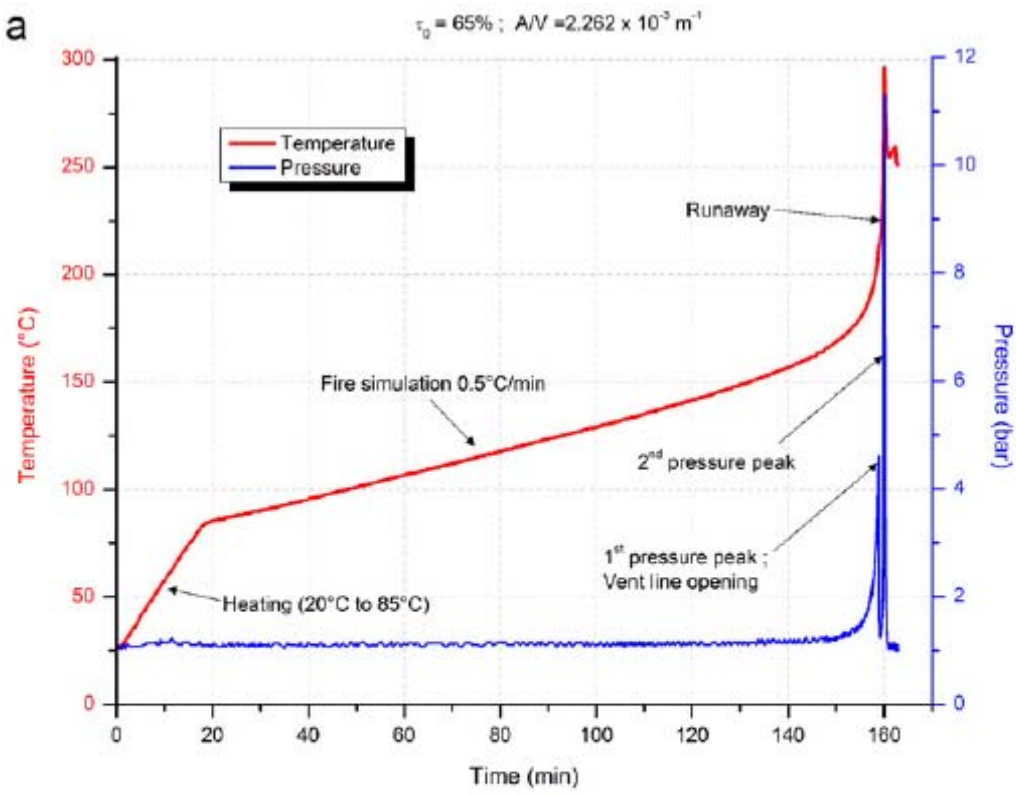

b $\quad \tau_{0}=65 \% ; A V=1.36 \times 10^{-3} \mathrm{~m}^{-1}$

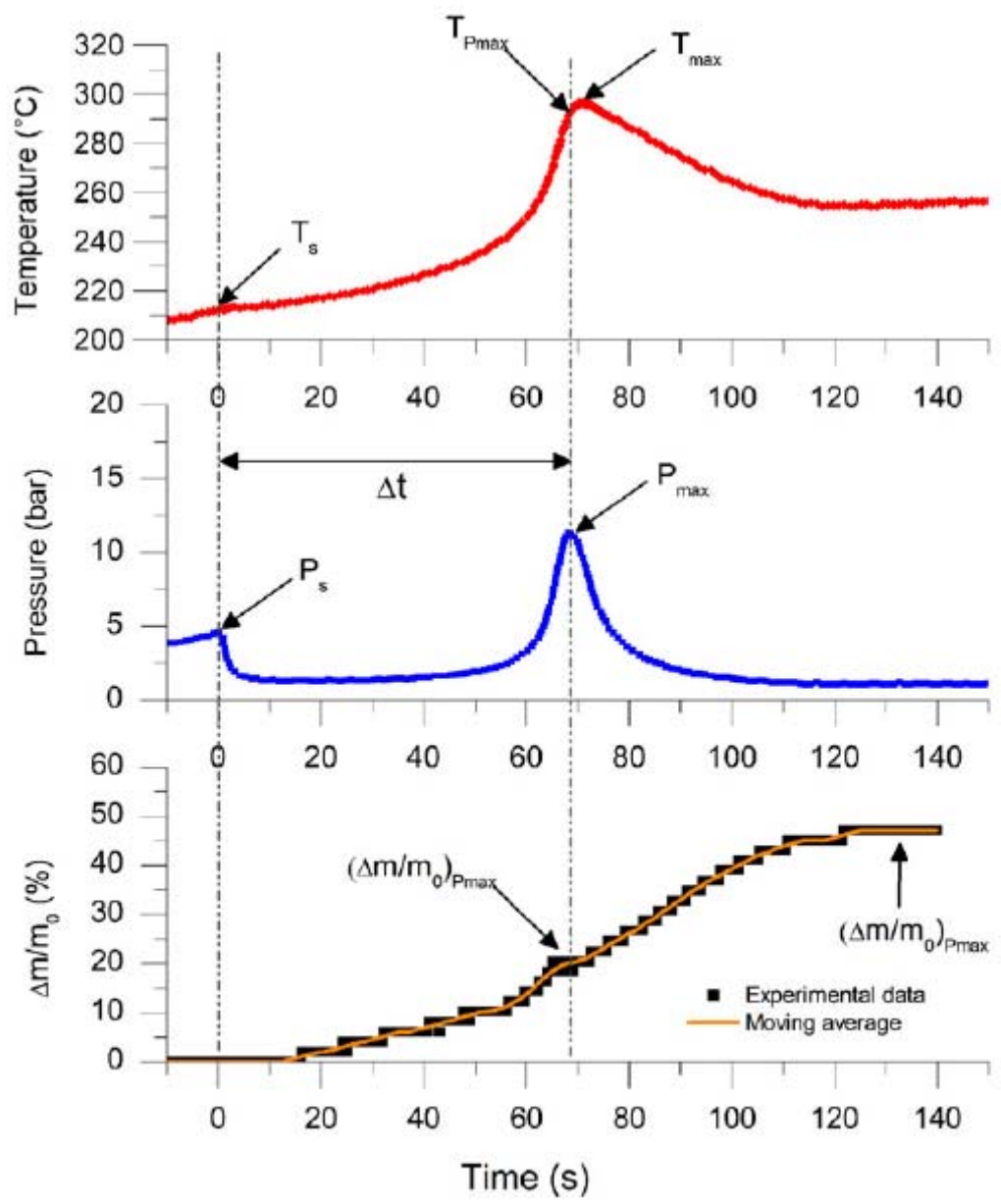

Figure 5: (a) Blowdown tests - typical pressure and temperature curves. (b) Blowdown tests - typical pressure, temperature and vented mass curves. 
Journal of Hazardous Materials, 2011, 191(1-3), 8-18, doi:10.1016/j.jhazmat.2011.03.100

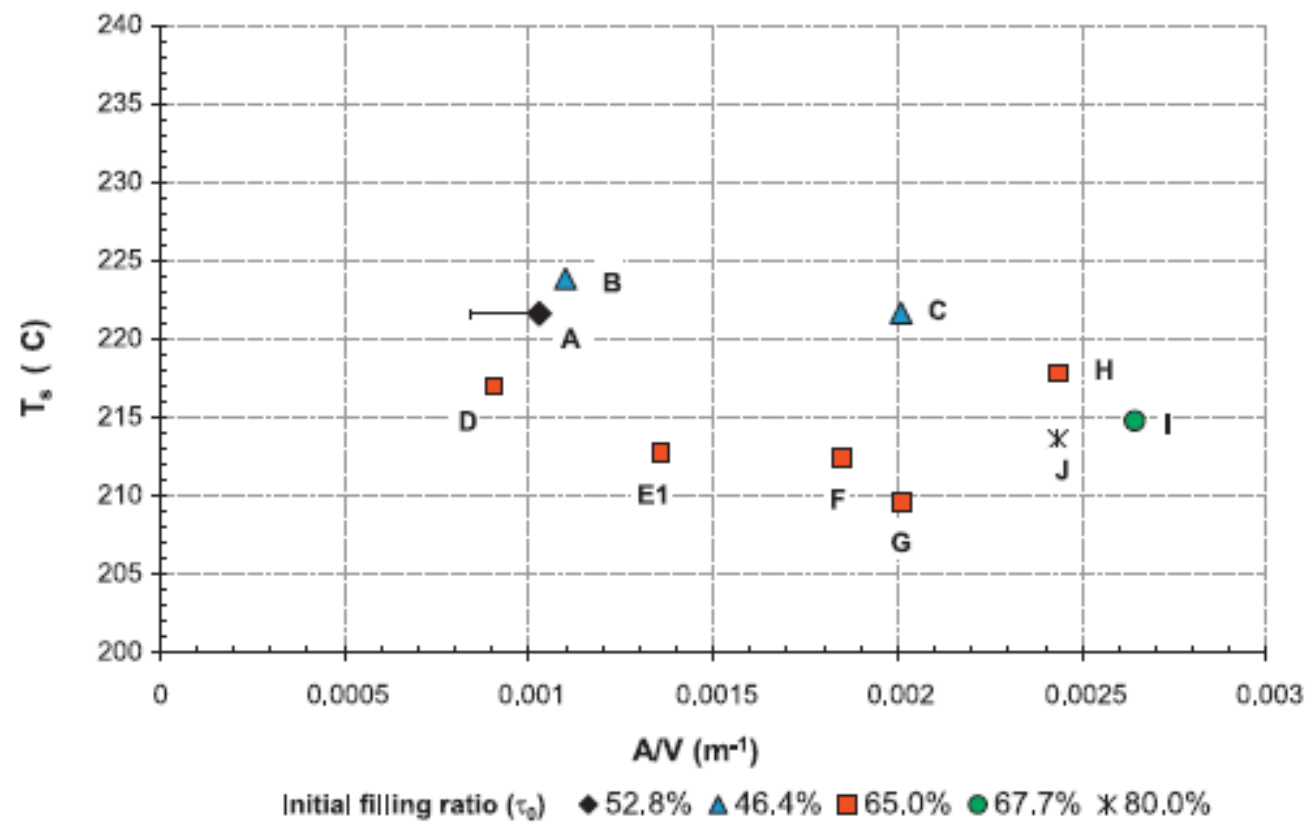

Figure 6: $T_{s}=f\left(A / V, \tau_{o}\right)$.

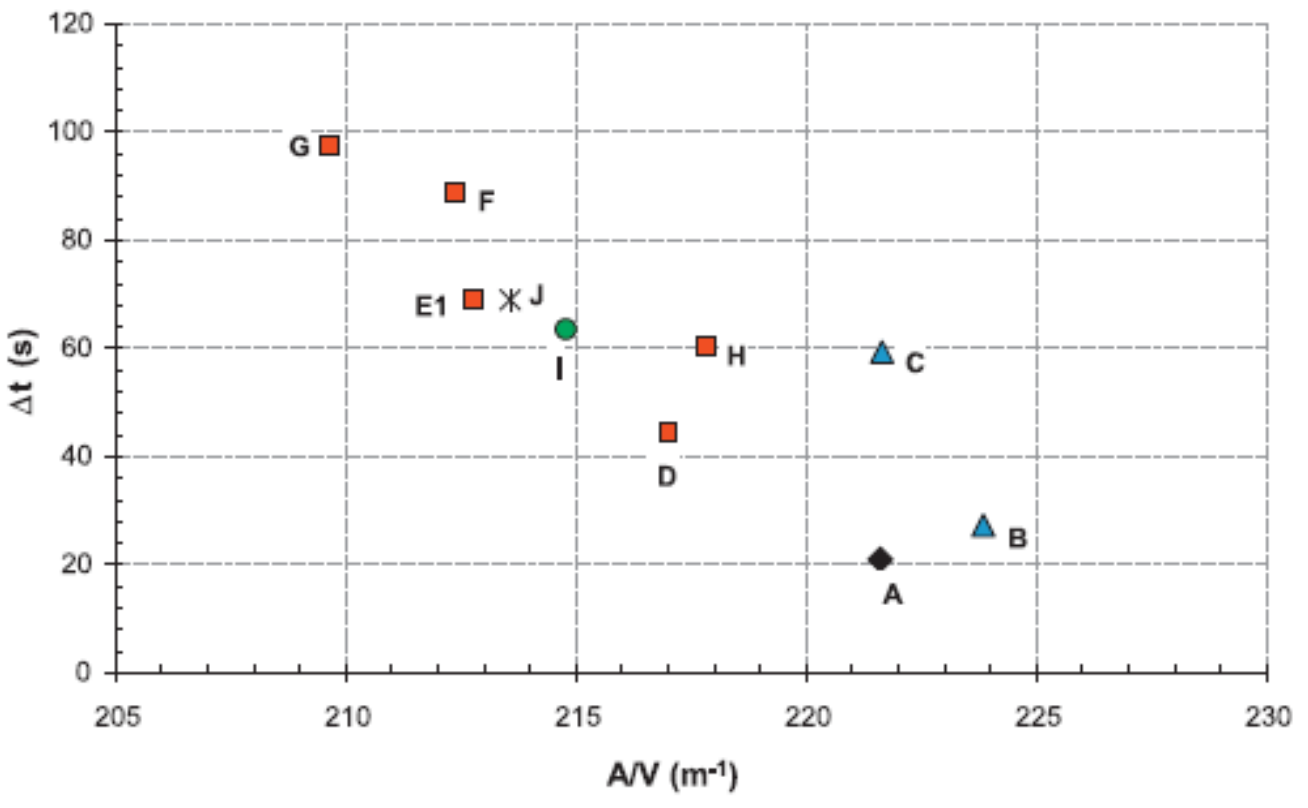

Initial filling ratio $\left(\tau_{0}\right) \quad 52.8 \% \Delta 46.4 \% \quad \square 65.0 \% \quad 67.7 \% * 80.0 \%$

Figure $7: \Delta t=f\left(A / V, \tau_{o}\right)$. 
Journal of Hazardous Materials, 2011, 191(1-3), 8-18, doi:10.1016/j.jhazmat.2011.03.100

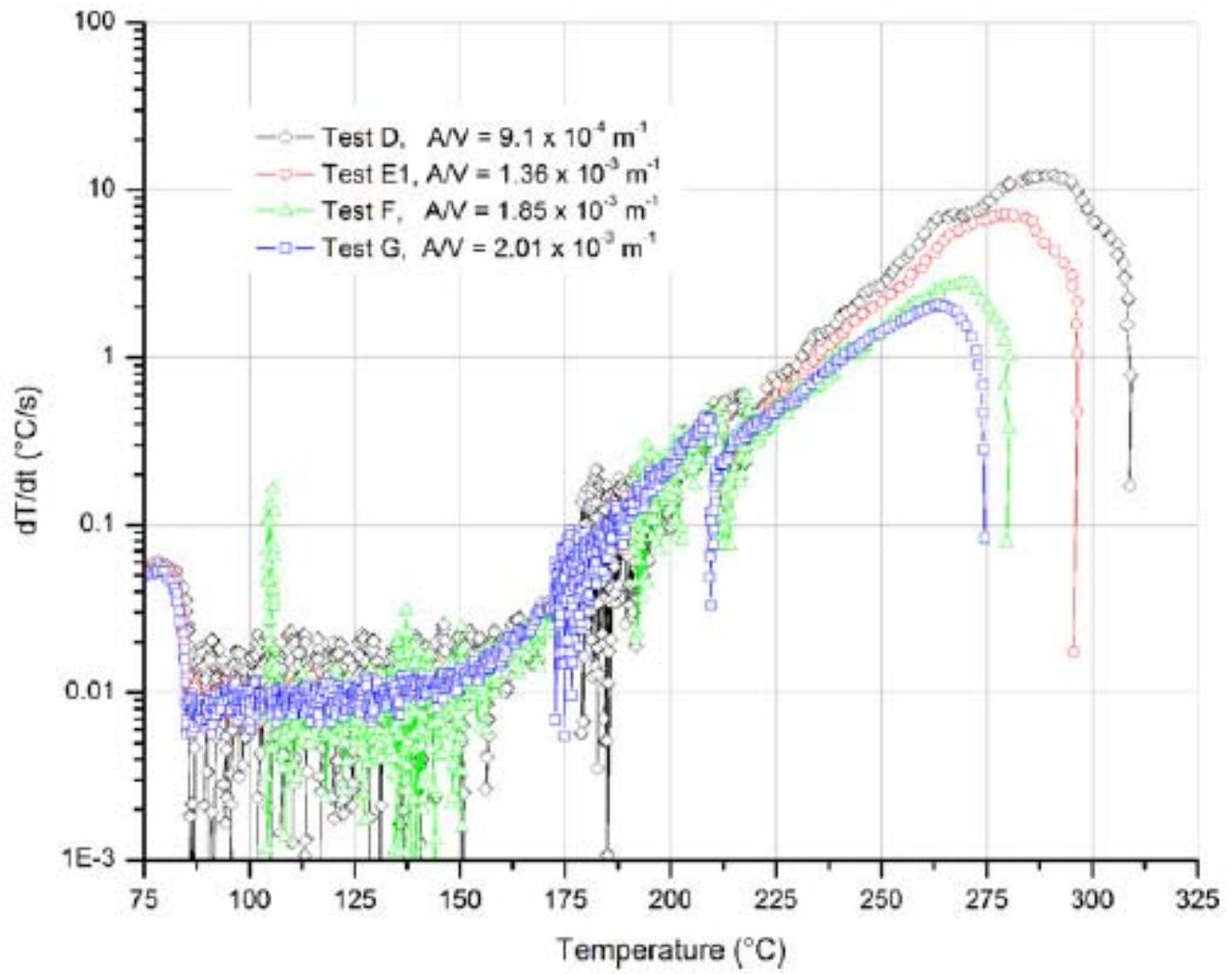

Figure 8: Blowdown tests $-d T / d t=f(T)$ curves with $\tau_{o}=65 \%$.
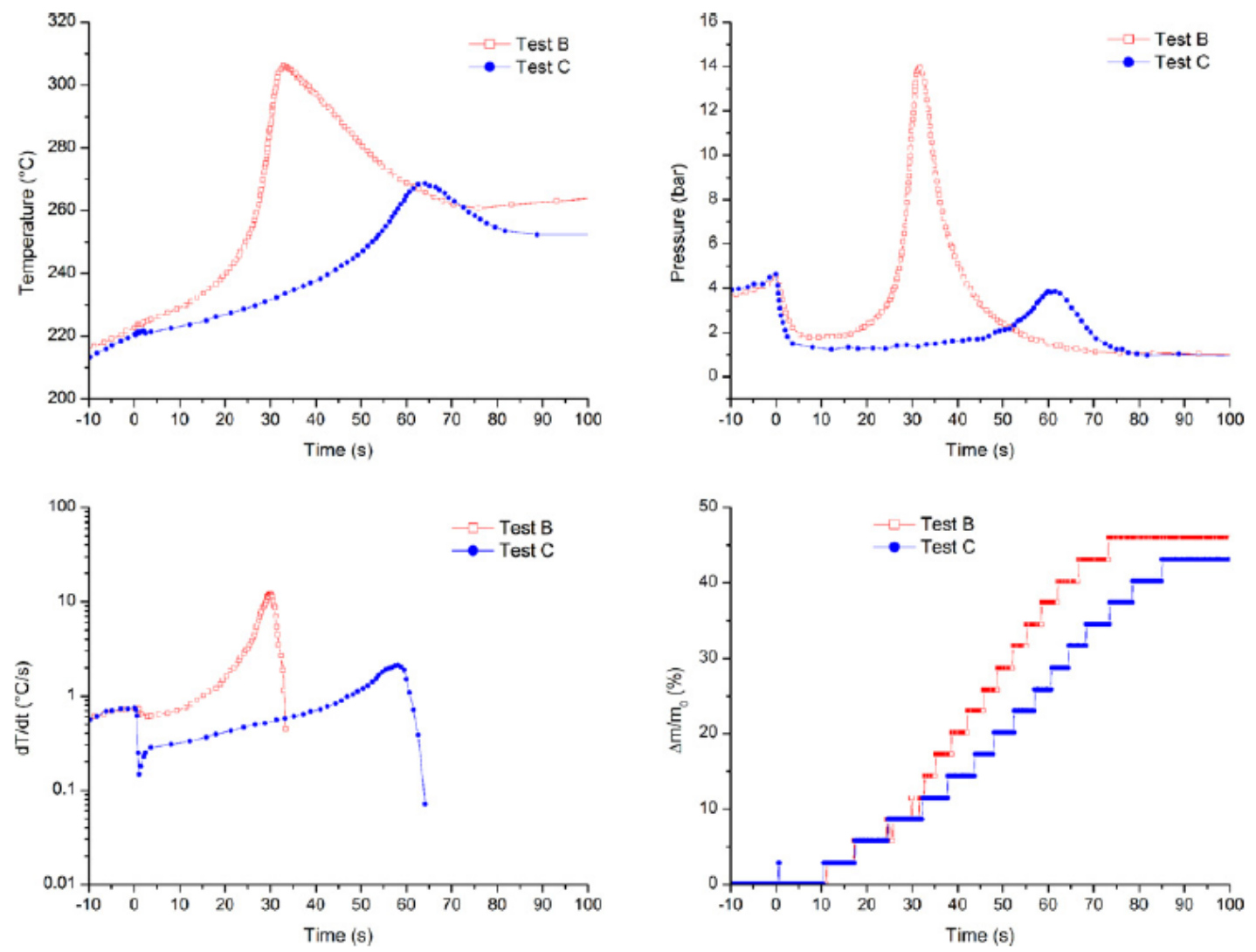

Figure 9: Comparison of vented mass and pressure histories between two tests with $A / V=0.00110 \mathrm{~m}^{-1}$ (test $B$ ) and $A / V=0.00201 \mathrm{~m}^{-1}\left(\right.$ test $C$ ). $\tau_{o}=46.4 \%$. 
Journal of Hazardous Materials, 2011, 191(1-3), 8-18, doi:10.1016/j.jhazmat.2011.03.100

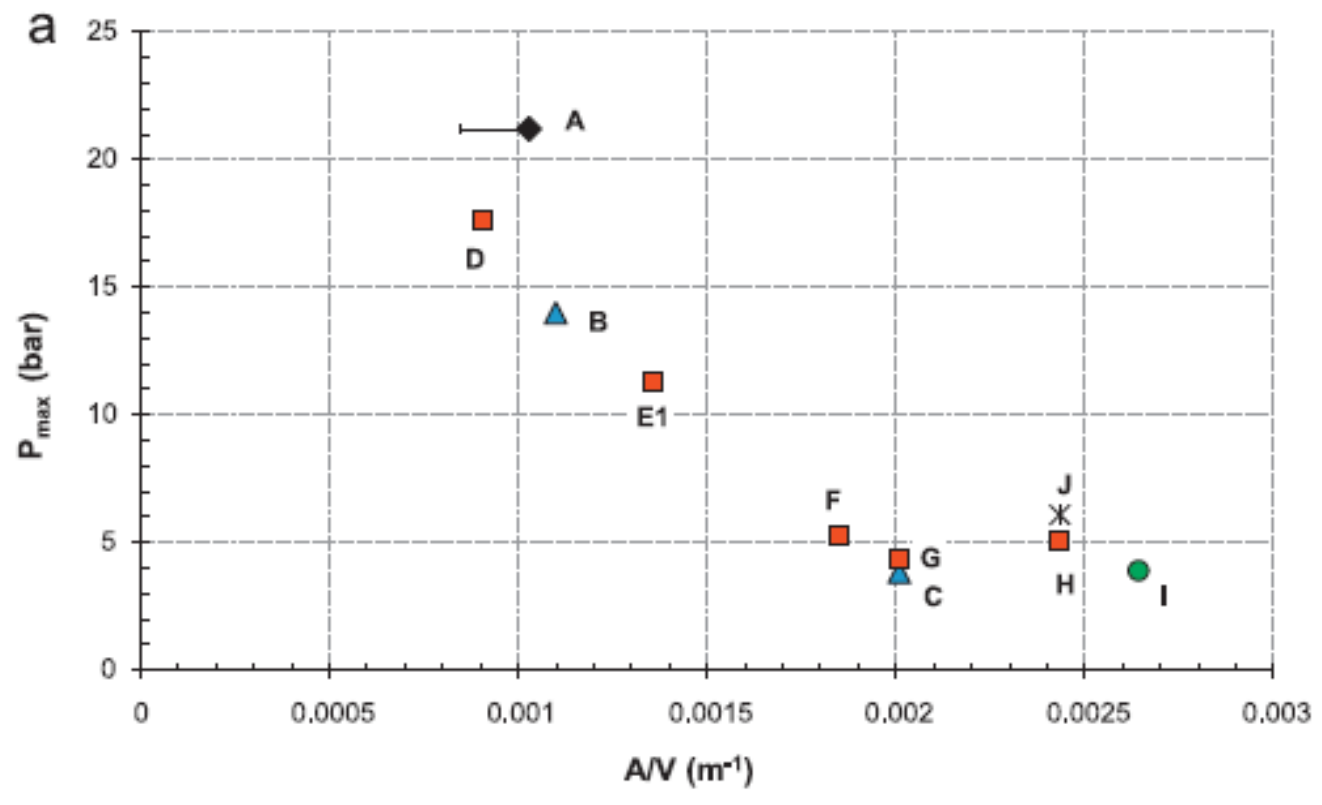

Initial filling ratio $\left(\tau_{0}\right) \quad 52.8 \% \Delta 46.4 \% \square 65.0 \% \bullet 67.7 \% * 80.0 \%$

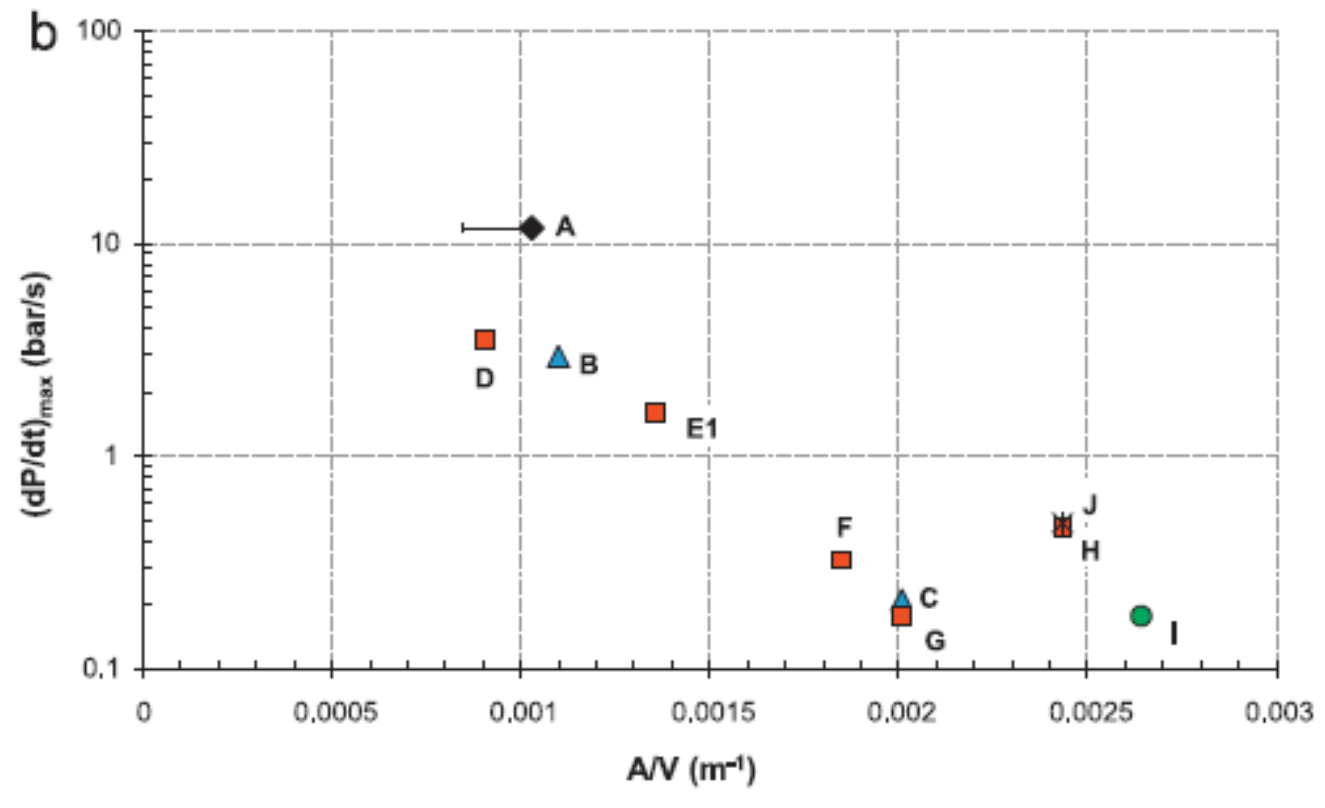

Initial filling ratio $\left(\tau_{0}\right) \quad \bullet 52.8 \% \Delta 46.4 \% \square 65.0 \% \bullet 67.7 \% * 80.0 \%$

Figure 10: Blowdown tests $-P_{\max }=f\left(A / V, \tau_{o}\right)(a)$ and $(d P / d t)_{\max }=f\left(A / V, \tau_{o}\right)(b)$. 
Journal of Hazardous Materials, 2011, 191(1-3), 8-18, doi:10.1016/j.jhazmat.2011.03.100

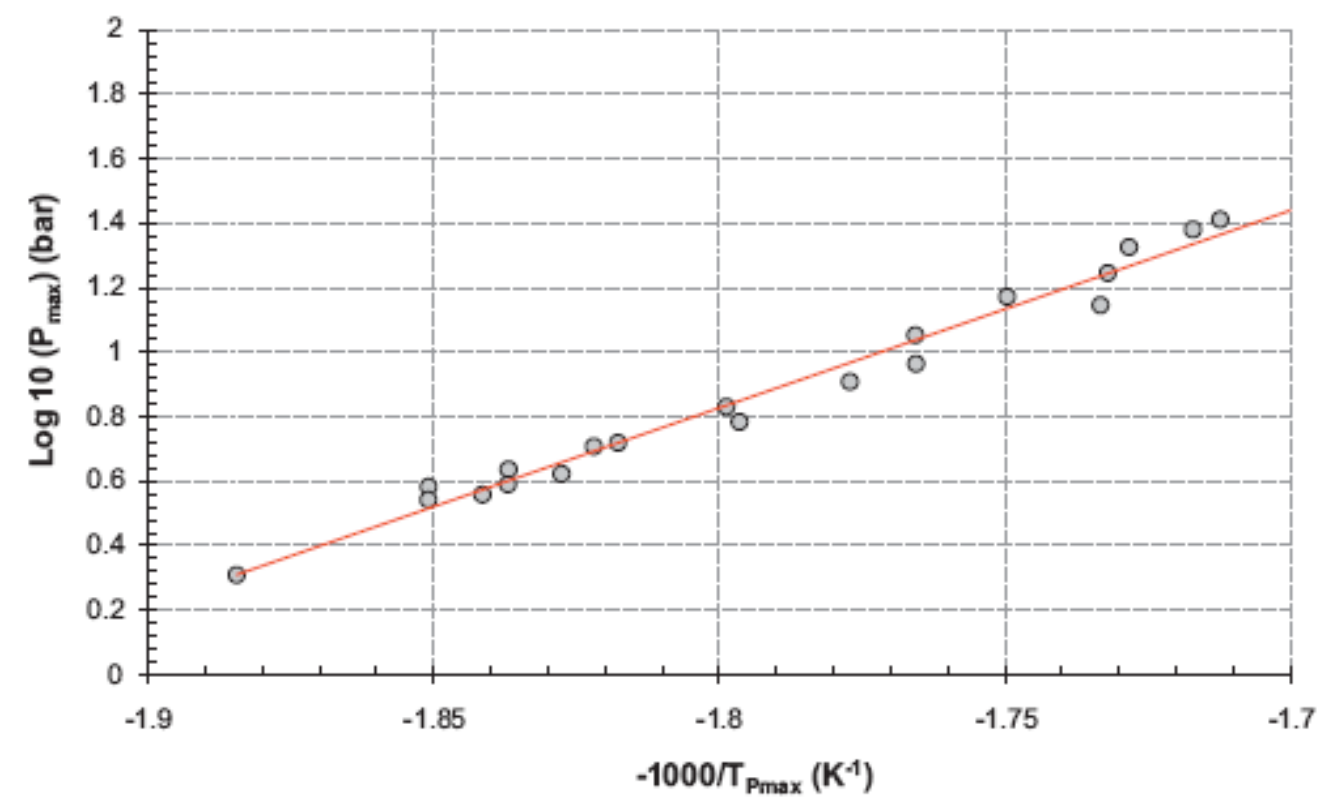

Figure 11: Blowdown tests - correlation between $P_{\max }$ and $T_{\max }$.
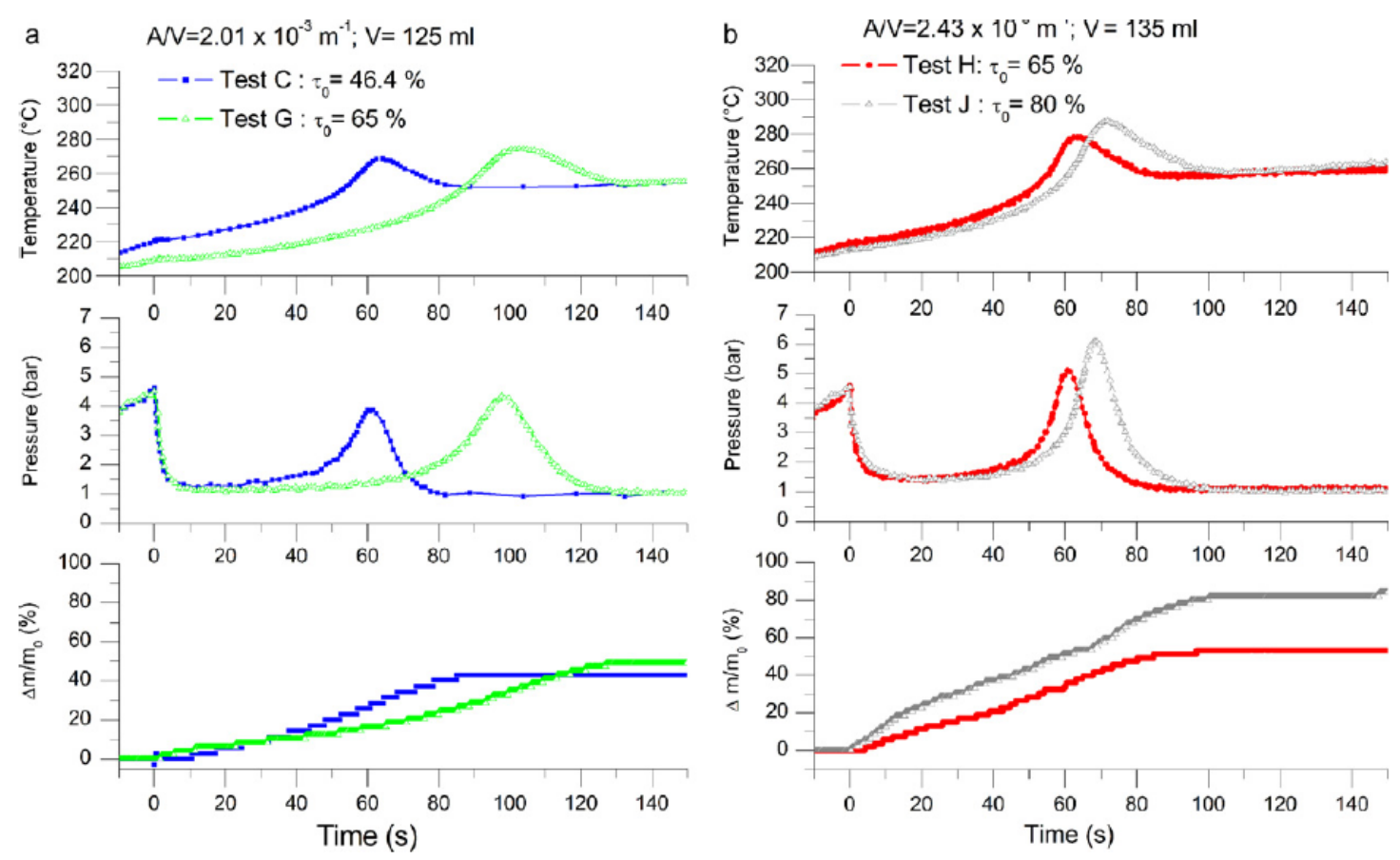

Figure 12: (a) Blowdown tests at $A / V=2.01 \times 10^{-3} \mathrm{~m}^{-1}-$ sensitivity to initial filling ratio $\tau_{o}$. (b) Blowdown tests at $A / V=2.43 \times 10^{-3} \mathrm{~m}^{-1}-$ sensitivity to initial filling ratio $\tau_{\text {o }}$. 
Journal of Hazardous Materials, 2011, 191(1-3), 8-18, doi:10.1016/j.jhazmat.2011.03.100
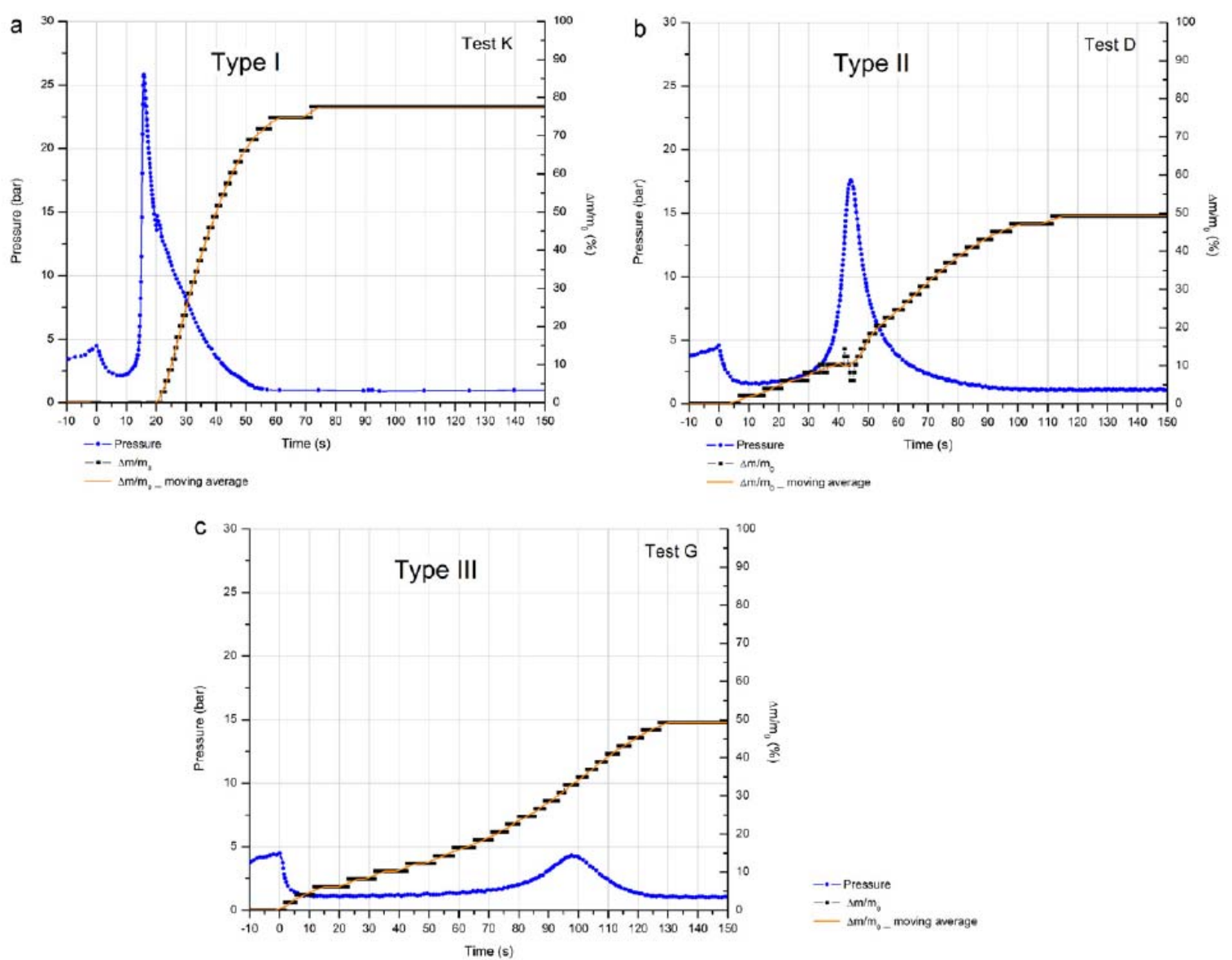

Figure 13: Blowdown tests - vented mass profiles - (a) type I, (b) type II and (c) type III.

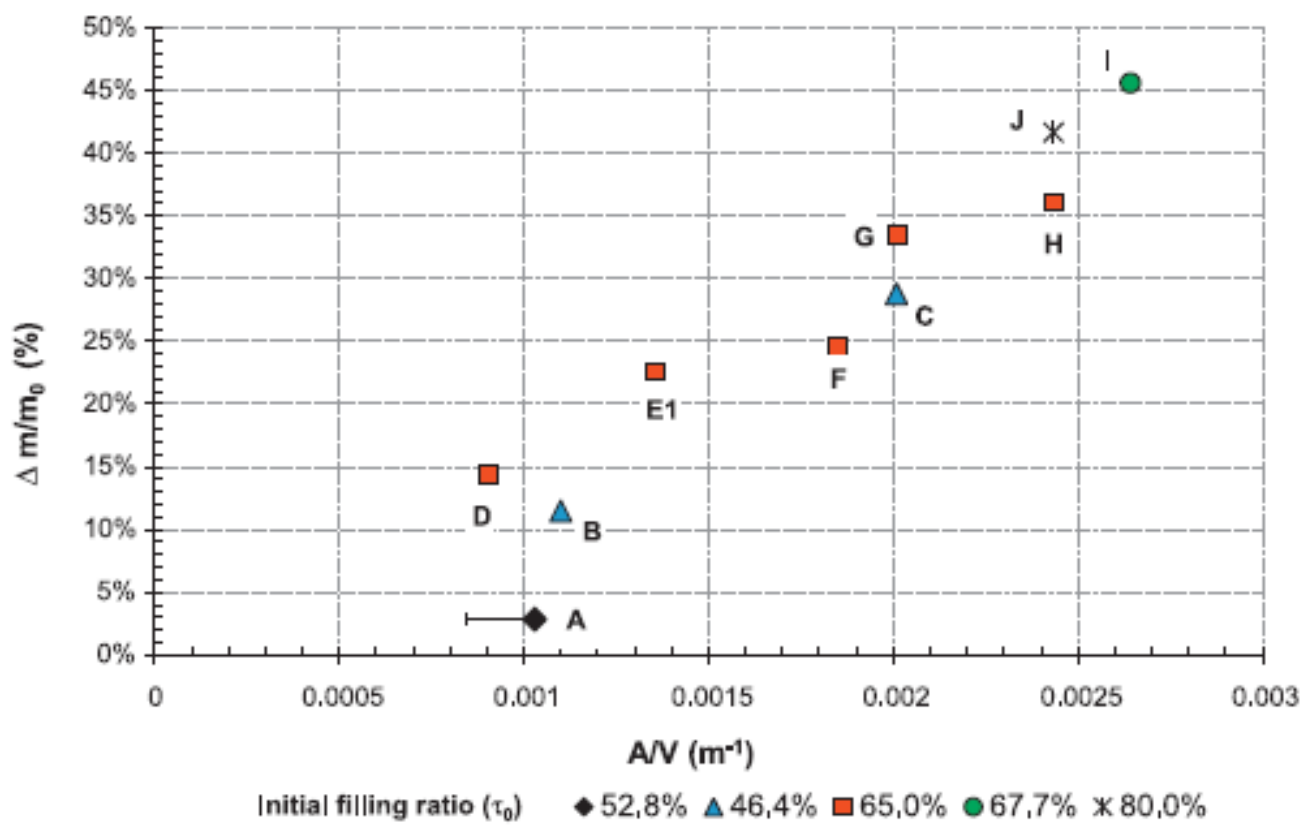

Figure 14: $\left(\Delta m / m_{o}\right)_{P \max }=f\left(A / V, \tau_{o}\right)$. 
Journal of Hazardous Materials, 2011, 191(1-3), 8-18, doi:10.1016/j.jhazmat.2011.03.100

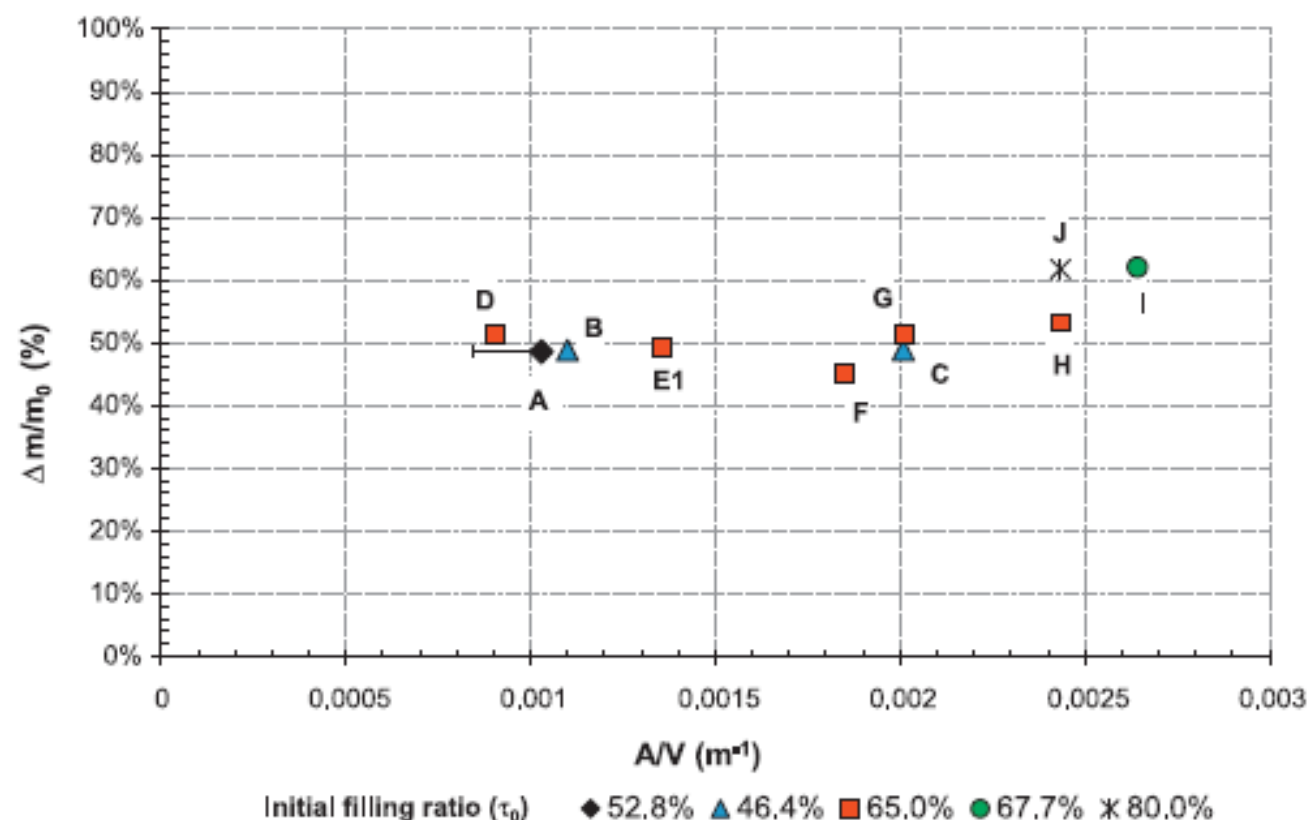

Figure 15: $\left(\Delta m / m_{o}\right)_{\text {total }}=f\left(A / V, \tau_{o}\right)$. 


\section{Tables}

Table 1: Closed cell test conditions and main results.

\begin{tabular}{|c|c|}
\hline $\begin{array}{c}\text { CHP Concentration } \\
(\% \mathrm{w} / \mathrm{w})\end{array}$ & 15 \\
Filling ratio (\%) & 52.4 \\
Initial mass (g) & 52.6 \\
Pend after cooling (bar) & 10.4 \\
$(\mathrm{dT} / \mathrm{dt})_{\max }\left({ }^{\circ} \mathrm{C} / \mathrm{s}\right)$ & 5.36 \\
$(\mathrm{dP} / \mathrm{dt})_{\max }(\mathrm{bar} / \mathrm{s})$ & 1.95 \\
$\mathrm{~T}_{\max }{ }^{\circ} \mathrm{C}$ & 250 \\
\hline
\end{tabular}

Table 2: Open cell tests - experimental conditions and main results

\begin{tabular}{|c|c|c|c|c|}
\hline Solution & \multicolumn{4}{|c|}{ 30\% CHP in 2,2,4-trimethyl-1,3-pentanediol diisobutyrate } \\
\hline$P_{o}\left(\mathrm{~N}_{2}\right)(\mathrm{bar})$ & 1 & 4.5 & 16 & 26 \\
\hline Filling ratio (\%) & 52.4 & 70 & 52.4 & 70 \\
\hline Initial reacting mass $(\mathrm{g})$ & 52.6 & 75 & 52.6 & 75 \\
\hline After test reacting mass (g) & 12.3 & 16.6 & 36.6 & 48 \\
\hline Mass loss (\%) & 75.8 & 77.9 & 30.4 & 36.0 \\
\hline$(\mathrm{dT} / \mathrm{dt})_{\max }\left({ }^{\circ} \mathrm{C} / \mathrm{s}\right)$ & 2.3 & 41.8 & 39 & 42 \\
\hline$(\mathrm{dP} / \mathrm{dt})_{\max }(\mathrm{bar} / \mathrm{s})$ & 0.063 & $\begin{array}{c}d P_{1} / d t=7.9 \\
d P_{2} / d t=0.83\end{array}$ & 2,3 & 3.25 \\
\hline$T_{\max }\left({ }^{\circ} \mathrm{C}\right)$ & 260 & 297 & 317 & 328 \\
\hline$P_{\max }(\mathrm{P} 1)(\mathrm{bar})$ & 1.95 & 12.7 & 20.5 & 32.5 \\
\hline $\mathrm{P}_{\text {end }}$ (bar) & 1.33 & 5 & $N / A$ & $N / A$ \\
\hline
\end{tabular}


Journal of Hazardous Materials, 2011, 191(1-3), 8-18, doi:10.1016/j.jhazmat.2011.03.100

Table 3: Blowdown tests conditions and main results.

\begin{tabular}{|c|c|c|c|c|c|c|c|c|c|c|c|c|}
\hline Tests & $\tau_{\mathrm{o}}$ & $\mathrm{V}$ & $\begin{array}{l}\text { Vent } \\
\text { A/V }\end{array}$ & $P_{\max }$ & $T_{\max }$ & $T_{\mathrm{s}}$ & $T_{P \max }$ & $\Delta \mathrm{t}$ & $\begin{array}{l}(\mathrm{dT} / \mathrm{dt}) \\
\max \end{array}$ & $\underset{\max }{(\mathrm{dP} / \mathrm{dt})}$ & $\left(\begin{array}{c}\left(\Delta m / m_{0}\right) \\
\text { total }\end{array}\right.$ & $\underset{\operatorname{Pmax}}{\left(\Delta m / m_{\mathrm{o}}\right)}$ \\
\hline & (\%) & $\mathrm{m}^{3}$ & $\mathrm{~m}^{-1}$ & bar & ${ }^{\circ} \mathrm{C}$ & ${ }^{\circ} \mathrm{C}$ & ${ }^{\circ} \mathrm{C}$ & $\mathrm{s}$ & ${ }^{\circ} \mathrm{C} / \mathrm{s}$ & $\mathrm{bar} / \mathrm{s}$ & (\%) & (\%) \\
\hline A & $5^{2.8}$ & $110 \times 10^{-6}$ & $1.03 \times 10^{-3}$ & $21.2 O$ & 309.0 & 221.6 & 305.5 & $21 . O$ & 36.8 & 11.90 & 48.6 & 2.8 \\
\hline B & 46.4 & $125 \times 10^{-6}$ & $1.10 \times 10^{-3}$ & 14.00 & 306.2 & 223.9 & 303.8 & 27.4 & $12 . O$ & 2.95 & 48.9 & 11.5 \\
\hline $\mathrm{C}$ & 46.4 & $125 \times 10^{-6}$ & $2.01 \times 10^{-3}$ & 3.83 & 268.7 & 221.7 & 267.1 & 59.4 & 2.1 & 0.21 & 48.9 & 28.8 \\
\hline $\mathrm{D}$ & 65.0 & $125 \times 10^{-6}$ & $9.05 \times 10^{-4}$ & 17.60 & 309.0 & 217.0 & 304.2 & 44.5 & 12.3 & $3 \cdot 51$ & 51.3 & 14.4 \\
\hline E1 & 65.0 & $125 \times 10^{-6}$ & $1.36 \times 10^{-3}$ & 11.30 & 296.5 & 212.8 & 293.2 & 69.0 & 7.1 & 1.59 & 49.2 & 22.6 \\
\hline E2 & 65.0 & $125 \times 10^{-6}$ & $1.36 \times 10^{-3}$ & 10.22 & 294.3 & 209.0 & 289.8 & 95.0 & 6.4 & 1.40 & 49.3 & 20.5 \\
\hline $\mathrm{F}$ & 65.0 & $125 \times 10^{-6}$ & $1.85 \times 10^{-3}$ & 5.24 & 280.3 & 212.4 & 277.0 & 88.8 & 2.8 & 0.33 & 45.1 & 24.6 \\
\hline G & 65.0 & $125 \times 10^{-6}$ & $2.01 \times 10^{-3}$ & 4.33 & 274.5 & 209.6 & 271.3 & 97.8 & 2.1 & 0.18 & 51.3 & 33.4 \\
\hline $\mathrm{H}$ & 65.0 & $135 \times 10^{-6}$ & $2.43 \times 10^{-3}$ & 5.10 & 278.1 & 217.8 & 275.7 & 60.6 & 3.9 & 0.47 & 53.2 & 36.1 \\
\hline I & 67.7 & $135 \times 10^{-6}$ & $2.64 \times 10^{-3}$ & 3.89 & 273.0 & 214.8 & 271.2 & 63.6 & 2.2 & 0.18 & 62.0 & 45.6 \\
\hline$J$ & 800 & $135 \times 10^{-6}$ & $2.43 \times 10^{-3}$ & 6.08 & 287.5 & 213.6 & 283.5 & 69.0 & 4.0 & 0.49 & 61.7 & 41.7 \\
\hline $\mathrm{K}$ & 52.7 & $110 \times 10^{-6}$ & $<0.96 \times 10^{-3}$ & 25.80 & 315.9 & 219.9 & 310.9 & 15.9 & 52.8 & 17.90 & 77.6 & $O . O O$ \\
\hline
\end{tabular}

